\title{
Model Development in Stimulating Entrepreneurship Motivation for Former Indonesian Migrant Workers in East Java
}

\author{
Awang Setiawan Wicaksono ${ }^{1}$, Achmad Irfan Muzni ${ }^{2}$ \\ ${ }^{1,2}$ Muhammadiyah Gresik University
}

\begin{abstract}
This research aims to apply the model of entrepreneurial motivation by combining stimulation with emphasis on the utilization of local area to the former Indonesian migrant workers (TKI) that has returned from overseas and has no plans to back off out of the country. This research was conducted in the area of East Java. This type of research is a qualitative study using Participatory Action Research. Where the method of data collection was done by using the method of observation and in-depth interviews to key informants and other research subjects, in addition to the data collection is done by using a Focused Group Discussion (FGD) and workshops with subjects and other parties concerned. As a follow up of the results, the researchers conducted a workshop with stakeholders will provide guidance to the group of subjects who are involved to realize the knowledge and skills that have been acquired to significantly develop commercial real effort to harness the potential of the existing local area.
\end{abstract}

Keywords: Model Development In Stimulating Entrepreneurship Motivation, former Indonesian Migrant Workers, East Java

\section{Introduction}

\section{Research Background}

The decision for Indonesian migrant workers (TKI) to work abroad is not the the best decision they have made, but this decision is one of the best of the many options that are less suitable for the Indonesian migrant workers (TKI). The majority of their main goals to be set off more workers because of the magnitude of the urge to seek instant capital big difference from differences in the living standards of other countries, meaning that they expect to benefit from the instantaneous difference larger salary given in another State for work the same is done in this country.

Based on the data in BNP2TKI, as revealed by the head of BNP2TKI Jumhur Hidayat,in a public lecture at the IPB campus on last April $22^{\text {nd }} 2012$, He told that more than $80 \%$ of the workers came from families with a peasant culture, which means the hard work are common encountered daily. The migrant workers going abroad aiming to get a majority of the capital is expected to be used for the development of entrepreneurial businesses in their hometown. Indeed they are also aiming to make this profession as a permanent livelihood, but not many choose to like it.

Unfortunately the reality that often occur in the field, after a few years abroad and the workers managed to collect a certain amount of capital when they returned home to his native majority workers or former workers also called after this much then too complacent with the adequacy of financial which has been owned and forget the purpose of which is to collect initial working capital. In addition, quite a lot as well which turned out when returning to their home areas are still experiencing indecision and confusion will develop business andiri like. This happens due to lack of adequate preparation of the workers themselves in planning his future and still very aggravated with the lack of attention from the government and relevant agencies to develop a specific program that aims to provide guidance and assistance for the former workers when they decide to return to their home areas.

Hence from this study with a team of researchers aims to provide insights in entrepreneurship and refresher guidance on the location of the former workers in this study carried out to begin to develop their own business together in an integrated group by utilizing the potential of local resources there are in the surrounding area to be developed into a potential domestic economic development in the family and society sustainable.

\section{Research Finding Target}

The results of this study are targeted to apply the model of mentoring program for former workers in initiating and developing the independent entrepreneur that later can support family economy and support the economic progress of the region by utilizing widely owned capital has since become migrant workers as well as by utilizing local potential in the regions where they originated.

\section{Literature Study}

\section{Deffinitions of Entrepreneur}

According to Norman M. Scarborough and Thomas W. Zimmerer (1993: 5), "An entrepreneur is one WHO creates a new business in the face of risk and uncertainty for the purpose of Achieving profit and growth by identifying opportunities and assembling the Necessary resources to capitalze on Reviews those opportunities ". Entrepreneurs are people who have the ability to see and assess business opportunities; resource-gathering resources needed to take appropriate actions, taking advantage from having the nature, character and willingness to create innovative ideas into real world creatively in order to achieve success / increase revenue.

\section{Volume 4 Issue 12, December 2015}




\section{International Journal of Science and Research (IJSR) \\ ISSN (Online): 2319-7064 \\ Index Copernicus Value (2013): 6.14 | Impact Factor (2014): 5.611}

Raymond Kao, an expert on entrepreneurship (in Hendra et al: 2008), said that the entrepreneur is a person who creates prosperity and the process of adding value through the incubation of ideas, integrate resources, and make the idea a reality. Meanwhile, according Kasali (2010) entrepreneur is essentially a human character who brave the odds and action oriented.

Winardi (2003) explains that in 1776 Adam Smith, father of economics, in his masterpiece works entitled: An Inquiry into the Nature and The Wealth of Nations, described an entrepreneur as an individual who creates an organization for commercial purposes. But she also saw an entrepreneur as a person who has the foresight, until he was capable to detect potential demand for goods and certain services. In Adam Smith's perception, entrepreneurs react to economic changes, until they become economic actors (economic agents) which transforms the request into an offer.

From the opinions of the above it can be concluded that the entrepreneur is a man who can create an innovation, good at reading the odds, and then take an action. In essence, an entrepreneur are the ones who have to apply the entrepreneurial character and nature of entrepreneurship in his life. In other words, entrepreneurs are the ones who have the creativity and innovative spirit that is high in his life.

\section{Entrepreneurial characteristics}

David E. Rye (in Saiman: 2009) to formulate the characteristics of the profile and characteristics of entrepreneurs that stands out as follows: (1) Achievement of high, which would rather work hard with experts to obtain achievement; (2) a risk taker, that is not afraid to take risks, but will avoid high risk whenever possible; (3) breaking problem, which quickly identify and solve problems that may hinder its ability to achieve goals (4) Seeker status, ie if it does not acquire the status / recognition it will interfere with the mission of the business; (5) The energy level is high, that is dedicated and willing to work long hours to build a business; (6) Believe in yourself, which relies on a high level of self-confidence in achieving success; (7) Institute of emotion, that is if it does not obtain the emotional connection it will interfere with a successful business; (8) Personal satisfaction, which considers the structure of the organization as an obstacle to the achievement of high goals.

\section{Motivation and Goals Being TKI}

Based on data BNP2TKI known if the majority of Indonesian migrant workers choose to migrate abroad to be caused by the large boost workers held to obtain working capital in large numbers but do not require a long time to get it. This is due to the significant difference in the amount of wages salary received by each of the workers at the time he was abroad with if he is doing the same job in the country. Besides opening up a great opportunity to try their luck abroad as migrants become one of the drivers of the emergence of one's intention to make choices as migrant workers. (www.bnp2tki.go.id)

\section{Activity of TKI Once the Return}

Based on the statement of Chief BNP2TKI, more than $80 \%$ of Indonesian migrant workers who work abroad comes from a family of farmers (www.bnp2tki.go.id). Because of this, when they returned to their home areas merekaakan rerun the routine activities as a farmer. But very few of them are able to actively use his experiences while abroad to be used in improving existing local potential region.

\section{Problem Formulation}

The problem of this research is to find how the pattern of a model appropriate mentoring program for former workers in initiate and develop the independent entrepreneur that can later be used as the support of family economy and supporting the economic progress of the region by utilizing widely owned capital has since become migrant workers as well as with utilize local potentials.

\section{Methods}

\section{Research Design}

This type of research is a qualitative study using data mining approach to directly use the method of Participatory Action Reseach. In this study is used to explore various forms of existing problems and attempt to formulate solutions to the problems. This method is also referred to as the method of grounded research, because this research is not only satisfy the curiosity alone but involvement of researchers in terms of community organizing and community empowerment are critical success factors of this research.

\section{Research Location and Level of Analysis}

Research sites used in this study is Ngawi East Java Province. While the level of analysis in this study is in the scope of the social group of former workers who are in the area Ngawi. While the unit of analysis of this study was to ex-workers who are directly involved in the research process as a research subject. In addition, to facilitate the main data mining research using key informants.

\section{Research Subjects}

The subjects of this study were the former Indonesian migrant workers who have returned from abroad and have not or have no desire to return to overseas but have a desire to develop independent businesses in the area of origin by using capital resources that have been owned. With the aim to focus the retrieval and processing of data, the subjects in this study focused on a group of former workers who are in rural districts Sidorejo Kendal Ngawi some 10 former workers.

\section{Methods of Data Collection}

The data collection process in this research is done by:

1) Observation this approach is used to monitor the daily activities of the subject and the process of implementation of the assistance that will be applied by recording any obstacles and problems that occur in practice.

2) Indepth Interview this approach is used to complement the methods of observation and interviews conducted in a structured and depth. This section is a part of the previous data retrieval techniques. Interviews were conducted either individually or in groups at the study site.

3) Workshop and Seminar, a method to disseminate the results of data processing on the parties involved in the

\section{Volume 4 Issue 12, December 2015}




\section{International Journal of Science and Research (IJSR) \\ ISSN (Online): 2319-7064}

Index Copernicus Value (2013): 6.14 | Impact Factor (2014): 5.611

research as well as a part of the process of evaluation and monitoring of the progress of the study investigators.

4) Focus Group Discussion (FGD), is one method of data collection is done through discussions with multiple participants using a particular theme or issue as the focus (Bambang Abrams, 2005 in Agus Dwiyanto (2005). Participants are research subjects and institutions related matters associated with labor, the village government agencies, non-governmental organizations, and public figures are involved.

\section{Methods of Data Analysis \\ The method of analysis used is multiple methods (triangulation method) that can occur between the method or can be in the method. Because of the method used to do with the object of study is the same as the problem and the same substance. Therefore, the data analysis is done by merging both kuantitaitif and qualitatively. Quantitative researchers to process data on the subject of entrepreneurship understanding obtained from the instrument given by instructors who provide materials on entrepreneurship during the workshop.}

Having performed a quantitative analysis of the data and then combined with qualitative analysis with triangulation method sehinggan according to Miles and Huberman (1992) emphasized that in the context of data analysis performed on the stages starting from data collection, data reduction, data presentation, and the conclusions of the data consist then drawing conclusions and verification of data.

\section{Research Results}

\section{Overview of Research Sites}

This study was conducted in Ngawi. At the beginning of this study, researchers deliberately focused this study on the former workers who had worked in Hong Kong as a more orderly system of employment for the workers in Hong Kong compared to some other countries the migrant destination in East Java such as Saudi Arabia and Malaysia. So it can make its own opportunities for workers who want to develop her potential and achieve success to return to their home areas. This is evident from the high quality of human resources workers who worked in Hong Kong when compared with workers who work in other countries. But over the research process, researchers obtained data if in the vicinity of the study also are former migrant workers from countries other than Hong Kong, which also provides an opportunity for them to develop themselves, including from Taiwan and South Korea. Therefore there is the subject of most of the former workers of the two countries.

While the level of analysis in this study is in the scope of the social group of former workers who are in the Village area Kersikan Ngawi. While the unit of analysis of this research is the ex-workers who are directly involved in the research process as a research subject. In addition, to facilitate the main data mining research using key informants. It is expected that this is the key informants who have the authority associated with this study, and have enough time to be able to provide information to the researcher. Besides supporting informants who can provide data and research to support this as a family member of the former workers and the surrounding neighbors are also considered.

\section{Stages of Implementation Research}

\section{Excavation of Regional and Local Potential Potential of Human Resources}

The first stage in this research by extracting potential dimlai local and regional socio-cultural conditions and potential resources that exist in the vicinity of the study. This process is done by collecting information from the public through unstructured informal interviews to gather the community around the place (like a coffee shop, to the rice field hut mosque). It also made the process of extracting information by formally inviting communities and some local community leaders in the village Kersikan to sit together in a discussion forum and communicate potential keekonoian in the village Kersikan Ngawi district.

From the data mining results can be obtained if the majority of the information society in the field of agrarian berpencaharian village as farmers either alone or with a rice field as farm laborers. It makes them have a lot of free time, especially when the growing season is finished and waiting for the harvest. Practical peak hour of their activity only in the second period, while the majority of their time outside the many who are unemployed and a lot of time to switch professions fill the well as a bricklayer, laborer or a day laborer in various sectors.

For housewives who, during the planting and harvest also helped in the fields, when located outside the planting and harvesting automatically just fill the time with taking care of the house and mingle with neighbors so that almost no productive activity in the economy. These conditions can be optimized according to the researchers to carry out selfemployment, thereby increasing the economic strength of the community.

Meanwhile, if the review of the potential of village can be seen if the majority of the villagers have a large yard area that can be used to plant a variety of commodities with high economic value. At the time of this data collection process is to be obtained from the information society if the majority of the land owned by citizens have banana trees in large enough quantities, although the majority of these trees grow wild, but the majority have uniform types, namely wax bananas (medium-sized banana with texture soft and has a sweet taste slightly sour mix). From the information of the participants is unknown if the current crop of banana wax is often less acceptable because it feels that the market tends to be a little sweet sour mix, so that the price given was very low and often not even sold in the market so wasted with useless, because that the researchers together with people involved in the discussion agreed to process the banana commodity is the quantity of wax pretty much spread in the village Sidorejo District of Kendal that has a higher economic value.

At this stage of research subjects whose background as former workers are also given insight enrichment related and cultural differences between the living standards of the local villagers with standard culture and society in which he

\section{Volume 4 Issue 12, December 2015}




\section{International Journal of Science and Research (IJSR) \\ ISSN (Online): 2319-7064}

Index Copernicus Value (2013): 6.14 | Impact Factor (2014): 5.611

worked first. This was deemed necessary by the researcher to avoid bias the perception of background research subjects ex-workers so that they are not too affected by shadow culture and standard of living of the country of origin where they worked before which is very different from the culture and standards of living of the village where they stay current.

\section{Implementation of Entrepreneurship Workshop Accompanied With Expert Assistance}

Workshop scheduled to last for a full day (starting at 9:00 to 15:00 WB) to bring in two experienced experts in the field of agro-processing. This workshop is targeted to be able to be a stimulant to arouse enthusiasm for the subject in the process of expanding entrepreneurship independently by utilizing the potential that exists around it.

As known if the expected outcome of the workshop was to bring the entrepreneurial character at the beginning of this workshop researchers emphasize the psychological approach to not only introduce knowledge about entrepreneurship, but also to build character as an entrepreneur in the workshop participants with an enabling environment in order to provide stimulation for entrepreneurship that can strengthen the response and highlights the internal meaning of the subjects themselves so as to form an internal value (internal values) which, when amplified consistently and continuously will be memunculka character as selfemployment (Figure 6). So with this approach is expected to be formed entrepreneurial character as reflected in behavioral patterns of workshop participants.

Therefore, the approach pursued for this activity is carried in the constructive approach changes the paradigm of personal, environmental paradigm that will bring real behavior as a manifestation of the entrepreneurial character possessed. Workshop conducted by applying the model approach which seeks to stimulate motivation to approach entrepreneurship from three aspects of human learning in the cognitive, affective and psychomotor integrated.

\section{Periodic Monitoring and Evaluation}

Process monitoring is done periodically on each subject involved in the study a total of 12 people, in which the monitoring is done by two methods: (1) a method of on-site; the research team visited the site come directly subject and monitor the conduct of its business process performed and interviewed the subjects related to the process of natural subjects performed the operations. (2) virtual method, which is a process of monitoring and mentoring is done through telephone or email communications media, this method is more active because the communication process is not only initiated by a team of researchers, but can be initiated by the subject who directly contacted when there is a particular obstacle. By using this method can also be known which of the active subject to explore entrepreneurial activities undertaken and which only live in the absence of a desire to develop further.

The data in the monitoring and evaluation process is not only focused on the technical issues but also the psychological problems faced by the subject in the face of all obstacles that occur either intrinsic (from within the subject) and ekstrinik (from the surrounding environment, family and neighbors).

From the results of the monitoring can be known if after approximately two weeks, researchers get the data if all subjects had been able to follow the guidelines deal activity in the workshop with a good enough even to follow the guidelines they have to make adjustments beberapakali with conditions encountered.

\section{Implementation of the Focus Group Discussion}

Focus Group Discussion (FGD) was conducted in the format of an informal event involving the subject, some local community leaders and some residents. The event format is packed with advanced training to enhance the ability of the subject to self-employment, especially in terms of packaging and distribution of its products in order to reach a wider area of distribution by utilizing network owned introductions.

In this stage pretty much explored both the aspirations of the subject as well as entrepreneurs from other participants who have been paying attention to the products that have been produced and become early consumers of the product. Among the entries are: (1) the subject requires a touch of print technology in product decoration product banana chips that can be produced more quickly and not much tersetuh hand; (2) standard hygienic packaging so that the product is not easily damaged; (3) the production location away from city center, makes the subject difficult to market as a manufacturer if they are not helped by power marketers; (4) the need for the development of not only the main raw material of banana tubers but also that there are many surrounding environment; (5) to anticipate the competition due to the similarity of products produced in the capture consumers between subjects when the amount of production has increased, then the subjects involved suggested the need for further coordination in the marketing of products in the form of cooperatives; (6) takes the existence of advanced training related to the use of government programs in the development of small businesses such as financial bookkeeping training to businesses can obtain capital injections from PNPM as well as small loans from the bank but it is also necessary guidance from the relevant agencies to provide counseling related to the production and licensing standards health is required if the product will be marketed extensively.

\section{Evaluation Model Application Process Stimulation Entrepreneurial Motivation}

From the results of the final evaluation is done, it can be known if in this study, there are several obstacles that occur are: (1) study the location away an obstacle for researchers to be able to interact and perform as well as mentoring direct approach to the subject; (2) less profound interest in the field of business by mapping each of the subjects lead to decreased morale and motivation of the subject when faced few obstacles in starting entrepreneurial; (3) foster the spirit of entrepreneurship as part of the character of the individual requires a long time and the circumstances support an environment conducive to the development of this kearakter so due to less optimal conditioning of the two requirements above positive results in the vulnerability of the process change patterns of thinking and behavior and change the 


\section{International Journal of Science and Research (IJSR) \\ ISSN (Online): 2319-7064}

Index Copernicus Value (2013): 6.14 | Impact Factor (2014): 5.611

view to becoming self-employed decreased and weakened (4) as explained in front if the process to bring the character to be a behavior requires a thorough conditioning (holistic) of the internal self and the environment, the lack of a strong base option to become entrepreneurs rather than workers and lack the support of the monitoring and supervision of environmental about to do to make the value of monitoring is inherently entrepreneurial character as less able to grow optimally and appears as a pattern of behavior that is real.

\section{Entrepreneurship Obstacles For The former workers}

Based on the data that have been obtained can be known if the motivation to develop entrepreneurship requires the support and encouragement of the various parties that exist around the subjects that will develop entrepreneurial subjects terntunya besides sendri need to instill the values of self-employment on him. Here are the results of the analysis of research on a number of factors that could potentially become an obstacle in entrepreneurial motivation, especially in the former workers, among which are: (1) Less Wisely In Separate Consumer Needs And Desire; (2) Difference Between Standard Conditions adopted country Communities Around With Conditions; (3) Absence of Electoral Assistance Job For Former workers; (4) Absence of Mentoring And Figure Example (Role Models); (5) Trying Not Intent to entrepreneurship and entrepreneurship.

\section{Conclusion and Recommendations}

\section{Conclusion}

Of exposure to the above, the conclusion can be drawn a few things related to the problem have been following the discussion of this research ari brief exposure of this conclusion:

1) How to motivate entrepreneurship in former workers who want to start an entrepreneurial environment is to start providing stimulation to the subject by giving examples of figures surrounding dimasayarakat successful in entrepreneurship so as to trigger the interest of the subject and gave rise to an internal impetus to further explore the subject. After successfully bring up the subject of internal values and a strong desire to follow up with the entrepreneurship environment can provide reinforcement and encouragement so that the spirit of the subject are encouraged to develop the ability to follow the example of the figure is concerned.

2) The process to bring the character to be a behavior requires a thorough conditioning (holistic) of the internal self and the environment, the lack of a strong base option to become entrepreneurs rather than workers and the lack of the support of the monitoring and supervision of monitoring environment to perform the inherent make entrepreneurial character value as less able to grow optimally and emerge as a real pattern of behavior.

3) In applying the model needed mentoring relationship that synergies between development policy makers (government) with the surrounding environment due to the character as an entrepreneur can grow subjects need to be given a holistic treatment (cognitive, affective and psychomotor) that knowledge of entrepreneurial ability can be realized in behavior real.

\section{Recommendations}

In order to enhance the benefits of this research, the researcher can present some suggestions related to the research results obtained, namely:

1) Before the subjects involved in the mentoring process it is essential to the subject is given reinforcement to strengthen keyakin will be his choice for entrepreneurship, because the success of the mentoring process is determined by the seriousness of the subject in the following and perform each stage of the mentoring is done.

2) takes any interest in the business field mapping deeper areas of the business in order to obtain truly favored by the subjects. This becomes an important factor because the subject will ketertarika certain sectors will affect the success of the process of growing entrepreneurial character subject.

3) The process of implementation of a given model of stimulation should be applied on an ongoing basis with careful conditioning, as the result of behavioral changes in order to be kebiaasaan in the process will require the support of the environment and a fairly long time.

\section{References}

[1] Miles, Matthew B. \& Huberman, Michael A., 1992, Analisis Data Kualitatif, Jakarta: UI Press.

[2] Muhadjir, Noeng, 2002, Metodologi Penelitian Kualitatif, Edisi IV, Jogjakarta: Penerbit Raka Sarasin.

[3] Moleong, Lexy, 2003, Metode Penelitian Kualitatif, Jakarta: Rosda

[4] Nitisusastro, Mulyadi, 2012, Kewirausahaan dan Manajemen Usaha Kecil, Bandung: Alfabeta.

[5] Sarwono, Sarlito Wirawan, 2002, Psikologi Sosial: Individu dan Teori-Teori Psikologi Sosial, Jakarta: Balai Pustaka

[6] Suryana, 2013, Kewirausahaan Kiat dan Proses Menuju Sukses; Edisi Empat, Jakarta: Salemba Empat

[7] _ Hong Kong Jadi Pilihan Favorit TKI Madiun, www.bnp2tki.go.id, diakses 22 April 2013; Pukul 20.16 WIB.

[8]__ IPB-BNP2TKI Sepakat Kerjasama Usaha Produktif Bidang Pertanian Bagi TKI Purna, www.bnp2tki.go.id, diakses 22 April 2013; Pukul 19.46 WIB.

[9] __ Jumhur: Kepemilikan Usaha Kolektif Harus di Tangan Rakyat, www.bnp2tki.go.id, diakses 22 April 2013; Pukul 19.39 WIB.

Model Formulation of Entrepreneurial Mentoring For Stimulating Entrepreneurship Motivation In Former Overseas workers In East Java

From the explanation above, we can obtained a model formulation entrepreneurial mentoring for stimulation of entrepreneurship motivation in former overseas workers as follows: 
International Journal of Science and Research (IJSR)

ISSN (Online): 2319-7064

Index Copernicus Value (2013): 6.14 | Impact Factor (2014): 5.611

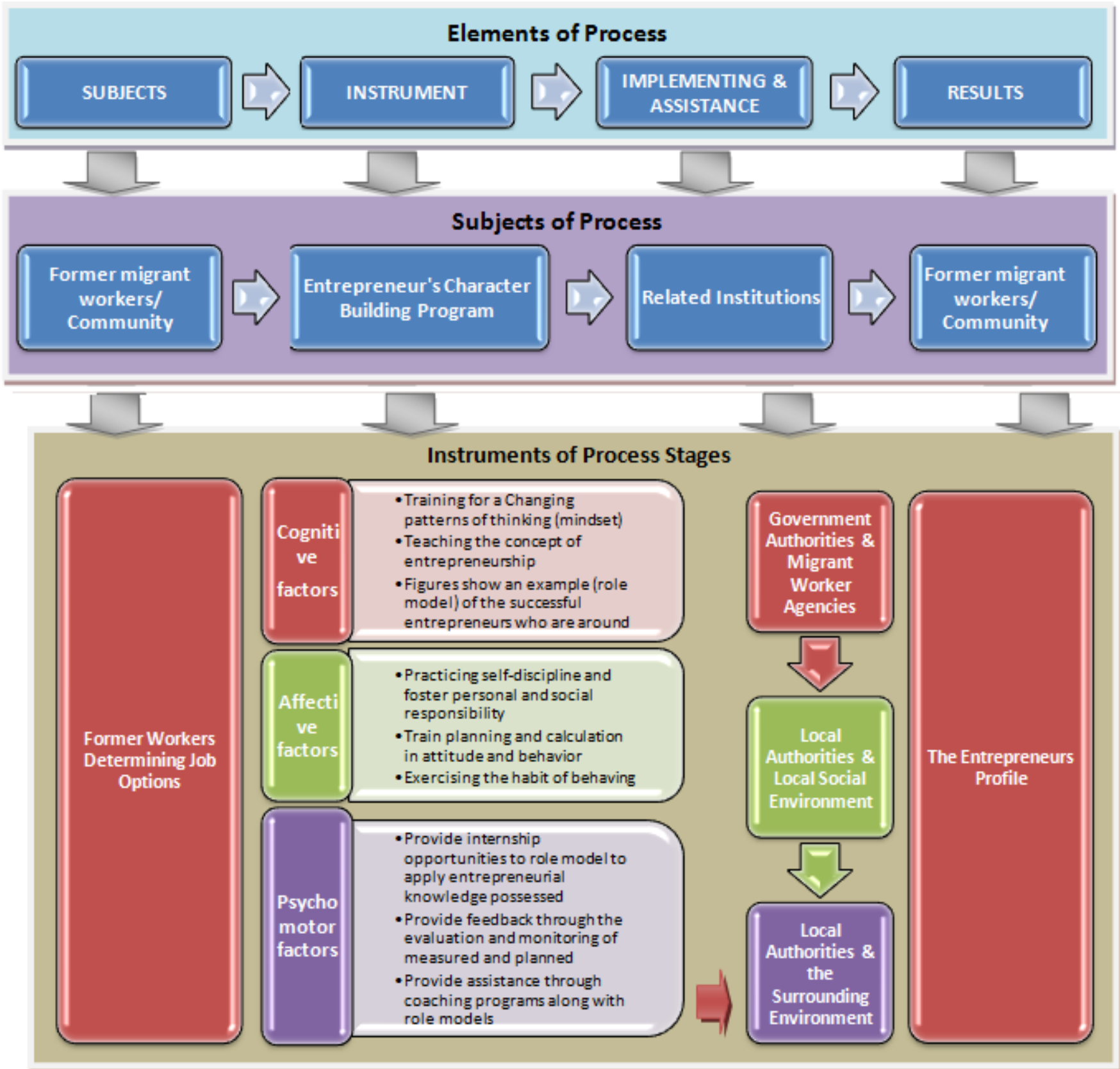

Figure 1: Model Formulation of Entrepreneurial Mentoring For Stimulating Entrepreneurship Motivation For Former Overseas workers In East Java

Volume 4 Issue 12, December 2015 www.ijsr.net 